\title{
Diversity of luteoviruses infecting faba bean (Vicia faba L) in Morocco, and their detection by the polymerase chain reaction
}

\author{
M Fortass ${ }^{1 \star \star}$, F van der Wilk ${ }^{1}$, RW Goldbach ${ }^{2}$, L Bos ${ }^{1}$, JFJM van den Heuvel ${ }^{\text {1* }}$ \\ 1 DLO Research Institute for Plant Protection (IPO-DLO), PO Box 9060, NL-6700 GW Wageningen; \\ 2 Department of Virology, Wageningen Agricultural University, Binnenhaven 11, NL-6709 PD Wageningen, The Netherlands
}

(Received 24 October 1995 ; accepted 29 November 1995)

\begin{abstract}
Summary - When surveying faba bean (Vicia faba $L$ ) for viruses in Morocco, members of the luteovirus group were found to be economically important. In order to further identify them, a number of faba bean samples showing symptoms indicative of luteovirus infection were serologically tested using polyclonal antisera for bean leafroll virus (BLRV), beet western yellows virus (BWYV), and subterranean clover red leaf virus (SCRLV), and two monoclonal antibodies which discriminate between BWYV and BLRV. Several serological reaction patterns were obtained which pointed towards a large variation in the luteovirus isolates studied. None of these isolates could be clearly identified as one of the luteoviruses known to infect legumes, although a number of them behaved like BWYV serologically. The potential of the polymerase chain reaction in detecting these luteoviruses was investigated, and a set of oligonucleotide primers was designed which specifically amplified a 535 bp fragment of the coat protein gene of known luteoviruses and of all the Moroccan isolates tested. In nucleic acid hybridization tests, the field isolates showed homology in nucleotide sequence among the Moroccan isolates and with BLRV, but not wih BWYV. In polyacrylamide gel electrophoresis, a purified Moroccan isolate was found to be different from BLRV and BWYV in coat-protein migration.
\end{abstract}

\section{Vicia faba L = faba bean / luteovirus / ELISA / PCR / Morocco}

Résumé - Diversité des lutéovirus infectant la fève (Vicia faba L) au Maroc et leur détection par la réaction d'amplification enzymatique. Un inventaire des virus de la fève au Maroc a démontré l'incidence économique des lutéovirus sur cette plante. Dans le but de mieux caractériser ces lutéovirus, des échantillons de fève, présentant des symptômes typiques des lutéovirus, ont été testés sérologiquement en utilisant des antisérums polyclonaux contre le virus de l'enroulement de la fève (BLRV), le virus de la jaunisse occidentale de la betterave (BWYV), le virus de la feuille rouge de trèfle souterrain (SCRLV) et deux anticorps monoclonaux discriminant le BLRV du BWYV. La diversité des profils de réaction sérologique obtenus montre qu'il existe une grande variabilité au sein des isolats étudiés. Aucun d'entre eux n'a pu être strictement assimilé aux lutéovirus infectant la famille des légumineuses, bien que certains isolats se soient comportés sérologiquement comme le BWYV. Le potentiel de la réaction d'amplification enzymatique $(P C R)$ pour la détection de ces lutéovirus a été exploré. Nous avons amplifié spécifiquement un fragment de 535 pb du gène codant pour la protéine de capside, aussi bien chez des lutéovirus connus que chez les isolats marocains testés. Lors des tests d'hybridation moléculaire avec une sonde correspondant au gène de la protéine de capside de différents isolats, des homologies de séquences nucléotidiques ont été montrées, d'une part entre les isolats marocains, et

* Correspondence and reprints

${ }^{\star \star}$ Present address: Département de phytopathologie, École nationale d'agriculture, BP S/40, Meknès, Morocco 
d'autre part entre les isolats marocains et le BLRV. Aucune homologie n'a été trouvée entre les isolats marocains et le BWYV. L'électrophorèse sur gel de polyacrylamide a montré que la migration de la protéine de capside d'un isolat marocain purifié est différente de celles des protéines de capside du BLRV et du BWYV.

Vicia faba L / lutéovirus / ELISA / PCR / Maroc

\section{INTRODUCTION}

Luteoviruses cause significant yield losses in a wide variety of crops. Characteristic symptoms are interveinal chlorosis, reddening of leaf margins, leaf rolling and stunting (Rochow and Duffus, 1981; Waterhouse et al, 1988). Originally the identification and classification of these viruses was based on information regarding host range, symptoms, aphid transmission parameters and serological affinities. Later it was understood that many of the luteovirus names were synonymous (Casper, 1988; Waterhouse et al, 1988). The International Committee on Taxonomy of Viruses now recognises 16 definitive species in the genus Luteovirus and 14 possible ones (Randles and Rathjen, 1995). Various approaches have been used to differentiate the luteoviruses and to evaluate their interrelationships. Among these are host range and vector specificity (Johnstone et al, 1984), serology (d'Arcy et al, 1989; Martin and d'Arcy, 1990), nucleic acid hybridization (Martin and d'Arcy, 1990 ), and polymerase chain reaction (PCR) followed by restriction-enzyme analysis of the amplified coat-protein gene (Robertson et al, 1991). Proper identification is essential not only regarding the taxonomy but also in breeding for resistance.

Three luteoviruses from different parts of the world have been reported to infect faba bean, viz bean leafroll virus (BLRV) (Quantz and Völk, 1954), beet western yellow virus (BWYV) (Duffus, 1964), and subterranean clover red leaf virus (SCRLV) (Wilson and Close, 1973). Other luteoviruses reported to infect faba bean are considered synonymous with BWYV (pea leafroll virus; legume yellows virus; Michigan alfalfa virus) and SCRLV (soybean dwarf virus) (Francki et al, 1991).

When surveying faba bean (Vicia faba $L$ ) for viruses in Morocco, samples with symptoms resembling those caused by a luteovirus were collected. Serological testing revealed various reaction patterns indicative of different luteoviruses or luteovirus strains (Fortass and Bos, 1991). In order to further identify these luteoviruses, a number of isolates were collected from different areas. This paper reports on further characteriza- tion of faba bean luteoviruses from Morocco by serology, PCR and molecular hybridization.

\section{MATERIALS AND METHODS}

\section{Sample collection and virus isolates}

Twenty faba bean plants with symptoms indicative of luteovirus infection were collected from the main faba bean-growing areas in Morocco and were kept in an aphid-proof glasshouse.

Leaf samples of alfalfa (Medicago sativa) infected with BLRV (Ashby and Huttinga, 1979), Physalis floridana infected with either BWYV (Van den Heuvel et al, 1990) or potato leafroll virus (PLRV) (Van der Wilk et al, 1989), and Trifolium subterraneum infected with SCRLV (Johnstone et al, 1982) were used as positive controls throughout the experiments. Faba bean plants either healthy or infected with broad bean mottle virus (BBMV) or bean yellow mosaic virus (BYMV) were used as negative controls.

\section{Serological testing}

The collected samples were tested for luteovirus infection in double-antibody sandwich enzyme-linked immunosorbent assay (DAS-ELISA), using polyclonal antisera as described by Clark and Adams (1977), and in triple-antibody sandwich ELISA (TAS-ELISA) using monoclonal antibodies (MAbs) according to Van den Heuvel et al (1990).

\section{Sample preparation}

Samples were prepared by grinding $0.5 \mathrm{~g}$ leaf material in $7 \mathrm{~mL}$ sample buffer $(0.02 \mathrm{M}$ sodium phosphate buffer $\mathrm{pH} 7.4$, containing $0.15 \mathrm{M}$ sodium chloride, $2 \%$ polyvinylpyrrolidone, $0.05 \%$ Tween 20 , and $0.2 \%$ ovalbumin).

\section{DAS-ELISA}

The polyclonal antisera to BLRV, BWYV, and SCRLV were kindly provided by L Katul (Institute for Biochemistry and Plant Virology, Braunschweig, 
Germany), JE Duffus (USDA, Agricultural Research Station, Salinas, California, USA), and GR Johnstone (Tasmanian Department of Agriculture, Tasmania, Australia) respectively. The $\gamma$-globulin fraction was partially purified by ammonium sulphate precipitation as described by Clark and Adams (1977), and conjugated with alkaline phosphatase according to Avrameas (1969). ELISA plates were coated with $1 \mu \mathrm{g} / \mathrm{mL}$ of the antibodies in $0.05 \mathrm{M}$ sodium carbonate, $\mathrm{pH}$ 9.6. The enzyme conjugates to BLRV and SCRLV were diluted $1: 1000$, and that to BWYV 1:2 000, in sample buffer.

\section{TAS-ELISA}

In TAS-ELISA, plates were coated with the antibodies to BWYV. As detecting antibodies, the MAbs WAU$A 12$ and $-A 24$, which discriminate between BWYV and BLRV (Van den Heuvel et al, 1990), were used respectively at 6000 - and 1000 -fold dilutions in sample buffer. Alkaline phosphatase-conjugated goat antimouse antibodies (Sigma) were applied at a 1000 -fold dilution to detect the immobilized MAbs.

In both types of ELISA, all samples including virusfree controls were tested in triplicate. Reagents were applied at $100 \mu \mathrm{L}$ per well. The presence of alkaline phosphatase was monitored by adding $1 \mathrm{mg} / \mathrm{mL}$ of para-nitrophenyl phosphate disodium salt in 10\% diethanolamine, $\mathrm{pH}$ 9.8. A sample was considered positive if the mean absorbance value at $405 \mathrm{~nm}$ was higher than the mean value of the negative controls plus three times their standard deviation (critical optical density).

\section{cDNA synthesis and PCR}

\section{Primers}

Initially, we used a set of luteovirus-specific oligonucleotide primers designed by Robertson et al (1991). The dowstream primer Lu4 (5' G-TCTACCTATTTGG $\left.3^{\prime}\right)$ corresponds to bases 4084 to 4097 of BWYV-RNA (Veidt et al, 1988) and bases 583 to 597 of BLRV-RNA (Prill et al, 1990). The upstream primer Lu1 (5' CCAGTGGTTRTGGTC 3'), degenerated at one position, pairs with bases 3562 to 3576 of BWYV-RNA. The length of the predicted PCR product is $535 \mathrm{bp}$.

\section{RNA extraction and cDNA synthesis}

RNA was extracted from $0.2 \mathrm{~g}$ of leaf material by grinding the tissue in liquid nitrogen, followed by extraction at $65{ }^{\circ} \mathrm{C}$ with a mixture $(1: 1)$ of phenol and extraction buffer $(0.1 \mathrm{M}$ glycine $\mathrm{pH} 9.5,0.1 \mathrm{M} \mathrm{NaCl}, 10 \mathrm{mM}$ EDTA). After centrifugation, the supernatant was extracted with phenol/chloroform, followed by chloroform extraction. Subsequently, the RNA was ethanolprecipitated. The pellets were washed with $70 \%$ ethanol, vacuum-dried and resuspended in $20 \mu \mathrm{L}$ of RNase-free water.
Annealing of the primer was carried out by heating $10 \mu \mathrm{L}$ extracted RNA with 50 pmol primer Lu4 for 5 min at $95{ }^{\circ} \mathrm{C}$, incubating for $10 \mathrm{~min}$ at $42{ }^{\circ} \mathrm{C}$, and chilling on ice. The cDNA was synthesized by adding an equal volume of a mixture containing $100 \mathrm{mM}$ Tris$\mathrm{HCl}, \mathrm{pH} 8.3,150 \mathrm{mM} \mathrm{KCl}, 6 \mathrm{mM} \mathrm{MgCl}_{2}, 10$ units/ $\mu \mathrm{L}$ of $M-M L V$ reverse transcriptase (BRL), $2.5 \mathrm{mM}$ dNTP, and 5 units RNasin. The reaction mixture was incubated for $1 \mathrm{~h}$ at $37^{\circ} \mathrm{C}$, then $10 \mathrm{~min}$ at $65^{\circ} \mathrm{C}$, and subsequently stored at $-20^{\circ} \mathrm{C}$ until needed.

\section{DNA amplification}

A total volume of $40 \mu \mathrm{L}$ PCR mixture containing $5 \mu \mathrm{L}$ of cDNA, $2.5 \mathrm{mM}$ dNTP, 5 pmol each of both primers Lu4 and Lu1, 2.5 units of Super Taq DNA polymerase (HT Biotechnology, LTD), $50 \mathrm{mM}$ Tris- $\mathrm{HCl}, 50 \mathrm{mM} \mathrm{KCl}, 7$ $\mathrm{mM} \mathrm{MgCl} 2,0.2 \mathrm{mg} / \mathrm{mL} \mathrm{BSA}$, and $16 \mathrm{mM}\left(\mathrm{NH}_{4}\right)_{2} \mathrm{SO}_{4}$. The samples were overlaid with $50 \mu \mathrm{L}$ of mineral oil and placed in a DNA thermal cycler (Perkin Elmer Cetus) programmed to give cycles at $95{ }^{\circ} \mathrm{C}(1 \mathrm{~min})$, $46{ }^{\circ} \mathrm{C}(2 \mathrm{~min})$, and $72{ }^{\circ} \mathrm{C}(10 \mathrm{~min})$, followed by 45 cycles at $94{ }^{\circ} \mathrm{C}(1 \mathrm{~min}), 46^{\circ} \mathrm{C}(1 \mathrm{~min}), 56^{\circ} \mathrm{C}(1 \mathrm{~min})$, and $72{ }^{\circ} \mathrm{C}(2 \mathrm{~min})$, and final cycles at $94^{\circ} \mathrm{C}(1 \mathrm{~min})$, $46{ }^{\circ} \mathrm{C}(2 \mathrm{~min})$, and $72{ }^{\circ} \mathrm{C}(10 \mathrm{~min})$. The PCR products $(10 \mu \mathrm{L})$ were analysed by agarose gel electrophoresis.

\section{Nucleic-acid hybridization tests}

\section{Preparation of labelled probes}

Radioactive labelled probes were generated to the 535 bp PCR products of the positive controls BWYV and $B L R V$, and Moroccan field isolate $V$ using a random priming kit (Boehringer, Mannheim). About $100 \mathrm{ng}$ of the total PCR products of BWYV, BLRV and isolate $V$ were run on a $1 \%$ low melting point agarose gel. The $535 \mathrm{bp}$ fragments were cut out of the gel and purified by two phenol extractions followed by ethanol precipitation. The pellets were resuspended in $30 \mu \mathrm{L}$ of sterile water. A sample of the extracted DNA $(10 \mu \mathrm{L})$ was submitted to labelling reactions according to the manufacturer's instructions. The labelled probes were purified by removing non-incorporated $\left[\alpha-{ }^{32} \mathrm{P}\right] \mathrm{dAPT}$ using a Sephadex G50 column.

\section{Southern blotting}

The PCR products, obtained from extracts derived from selected field samples and from the PLRV, BWYV, and BLRV positive controls as well as the healthy control, were subjected to agarose gel electrophoresis and transferred to $\mathrm{Hybond}-\mathrm{H}$ membrane (Amersham). Prehybridization and hybridization were performed as described by Sambrook et al (1989). Hybridization was carried out at $65^{\circ} \mathrm{C}$. Subsequently, blots were washed three times at $42^{\circ} \mathrm{C}$ in $2 \times$ SSC, $1 \times$ SSC and $0.1 \times$ SSC containing $0.1 \%$ SDS, prior to exposing them to $X$-ray films (Kodak). 


\section{Polyacrylamide gel electrophoresis (SDS-PAGE)}

Field isolate $V$ was purified from faba bean cv Aguadulce as described by $V$ an den Heuvel et al (1990). Purified isolate $V$ as well as the positive control BWYV and BLRV were subjected to SDS-PAGE according to Laemmli and Favre (1973). After electrophoresis, proteins were stained with Coomassie Brilliant Blue.

\section{RESULTS}

\section{Serological testing}

The reactivities of the field samples to the MAbs and polyclonal antisera used in DAS- and TASELISA are summarized in table I. All samples reacted with at least one antiserum or one MAb, implying that they were infected with a luteovirus. In DAS-ELISA, different reaction profiles were distinguished. They ranged from a reaction to all three antisera used (sample $B$ ) to no reaction to any of the polyclonal antisera (samples I, Y and $Z$ ). The majority of the samples reacted with the BWYV antiserum, whereas only four samples reacted with BLRV and seven with SCRLV antisera. The reaction patterns of the different isolates were independent of the geographical origin of the samples.

In TAS-ELISA, all samples except Ad reacted positively with the MAbs WAU-A12 and WAUA24, even those which were previously tested negative in DAS-ELISA. All samples reacted moderately with WAU-A24, whereas half of them were strongly detected by WAU-A12 and three of these were recognized by the BLRV antibodies in DAS-ELISA.

Table I. Reactivity ${ }^{a}$ of the faba bean samples showing luteovirus-like symptoms in DAS and TAS-ELISA.

\begin{tabular}{|c|c|c|c|c|c|}
\hline \multirow{2}{*}{$\begin{array}{l}\text { Sample } \\
\text { designation }\end{array}$} & \multicolumn{3}{|c|}{ Polyclonal antisera } & \multicolumn{2}{|c|}{ Monoclonal antibodies } \\
\hline & $B W Y V$ & $B L R V$ & SCRLV & A12 & A24 \\
\hline $\mathrm{B}^{\mathrm{b}}$ & 0.29 & 0.56 & 0.42 & 2.85 & 0.60 \\
\hline A & 0.31 & 0.48 & - & 1.33 & 0.50 \\
\hline D & 0.31 & 0.62 & - & 0.34 & 0.39 \\
\hline $\mathrm{T}$ & 0.30 & 0.53 & - & 1.47 & 0.48 \\
\hline $\mathrm{s}$ & 0.45 & - & 0.70 & 2.95 & 0.60 \\
\hline $\mathrm{F}$ & 0.31 & - & 0.42 & 2.36 & 0.42 \\
\hline V & 1.12 & - & 0.55 & 1.54 & 0.54 \\
\hline Ena & 0.27 & - & 0.66 & 0.55 & 0.46 \\
\hline E & 0.43 & - & - & 0.61 & 0.46 \\
\hline G & 0.33 & - & - & 0.87 & 0.43 \\
\hline M & 0.35 & - & - & 0.37 & 0.43 \\
\hline N & 0.38 & - & - & 0.46 & 0.35 \\
\hline 0 & 0.33 & - & - & 0.60 & 0.34 \\
\hline Q & 0.34 & - & - & 1.12 & 0.36 \\
\hline $\mathrm{x}$ & 0.85 & - & - & 1.41 & 0.42 \\
\hline $\mathrm{Ad}$ & 0.34 & - & - & - & 0.87 \\
\hline Dyt & - & - & 0.58 & 0.48 & 0.42 \\
\hline 1 & - & - & - & 2.90 & 0.49 \\
\hline Y & - & - & - & 0.62 & 0.37 \\
\hline Z & - & - & - & 0.93 & 0.40 \\
\hline$O D_{C}$ & 0.25 & 0.22 & 0.38 & 0.19 & 0.27 \\
\hline PLRV & 0.76 & - & - & 3.00 & 1.90 \\
\hline BWYV & 1.97 & - & - & 2.45 & 0.62 \\
\hline BLRV & - & 1.15 & - & - & 0.93 \\
\hline SCRLV & 0.28 & - & 1.28 & $\mathrm{nt}$ & $\mathrm{nt}$ \\
\hline
\end{tabular}

a Mean optical density at $405 \mathrm{~nm}$; ${ }^{b}$ samples arranged according to reactivity patterns; - = mean optical density did not exceed the critical optical density $\left(\mathrm{OD}_{\mathrm{c}}\right)$; $\mathrm{nt}=$ not tested 


\section{Detection by PCR}

In preliminary PCR experiments with BLRV, BWYV, and PLRV, the pair of primers Lu1 and Lu4 were found to specifically amplify sequences from PLRV and BWYV, but not from BLRV or the field isolates. By comparing the nucleic acid sequences of the coat protein genes of BWYV (Veidt et al, 1988) and BLRV (Prill et al, 1990), a new upstream primer was designed, VW66 (5' TACCAGTCCGTTCTGG 3'), which pairs with bases 3562 to 3576 of BWYV-RNA, and with bases 62 to 76 of BLRV-coat protein gene. Using this primer, a PCR product of about 530 bp was obtained from all luteovirus-infected control plants, but not from healthy controls (fig 1). No bands in the agarose gels were observed when applying the PCR procedure to extracts from faba bean samples infected with either a bromovirus (BBMV) or a potyvirus (BYMV), indicating that the set of primers Lu4/VW66 recognised specific luteoviral sequences.

All faba bean leaf samples with luteovirus-like symptoms subjected to PCR with the primer set Lu4/VW66 yielded a major PCR product of the expected size (fig 2), irrespective of the geographical origin. For some samples, additional bands of different sizes were also amplified.

\section{$\begin{array}{llllllll}1 & 2 & 3 & 4 & 5 & 6 & 7 & 8\end{array}$}

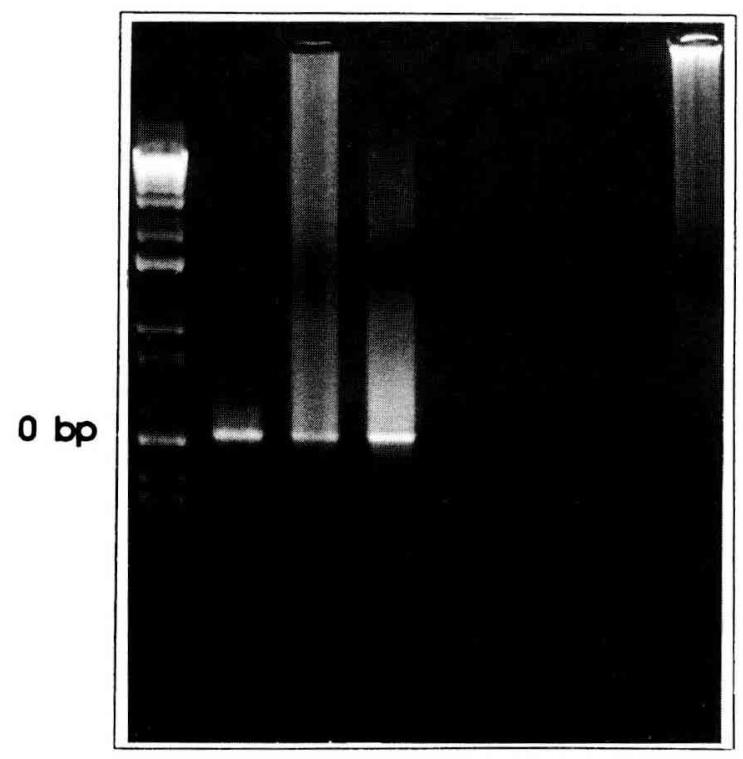

Fig 1. Agarose electrophoresis of PCR products. Lane 1: DNA size markers (BRL); lanes 2-6: PLRV, BWYV, BLRV, BYMV and BBMV respectively; lanes 7 and 8 ; healthy controls.

\section{Nucleic acid hybridization tests}

Four of the field isolates, varying in serological reaction and showing strong signals in PCR, were selected for the hybridization tests. Figure 3 shows that the 535 bp PCR product of BWYV hybridized with itself and also with the PCR product of BLRV, but no cross-hybridization was obtained with the PCR products of any of the field isolates. The probe derived from the $535 \mathrm{bp}$ PCR product of BLRV strongly tagged the homologous PCR product, and showed a weak crossreaction with BWYV as well as with the field isolates (fig 4). The Southern blot of the PCR products tested with the labelled $535 \mathrm{bp}$ PCR product of the isolate $V$ shows that it detected the PCR products from BLRV and from the field isolates tested, but not from BWYV (fig 5). Strikingly, these results indicate that the PCR products derived from the field isolates all shared a substantial sequence homology with BLRV but not with BWYV, which was not expected from the serological data.

\section{$\begin{array}{llllllllll}1 & 2 & 3 & 4 & 5 & 6 & 7 & 8 & 9 & 10\end{array}$}

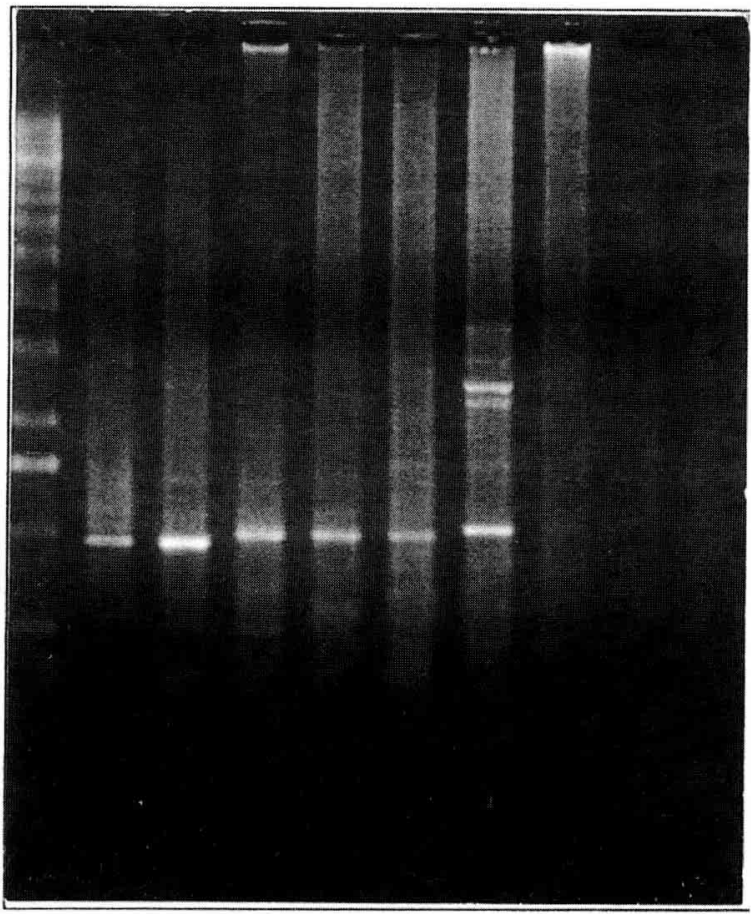

Fig 2. Agarose electrophoresis of PCR products. Lane 1 DNA size markers; lanes 2 and 3: PLRV and BWYV; lanes 4-8: luteovirus field samples D, V, Ena, Dyt and Ad respectively; lanes 9 and 10: healthy controls. 


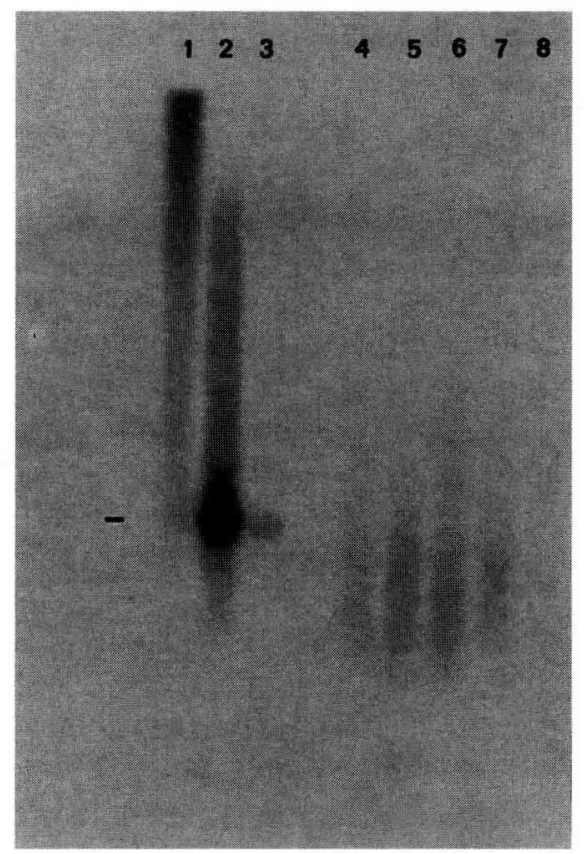

Fig 3. Southern blot of PCR products hybridized with a probe to the 530 bp PCR product from BWYV. Lanes 1-3: PLRV, BWYV and BLRV; lanes 4-7: luteovirus field samples D. Ena, $\mathrm{V}$, and Dyt respectively; lane 8: healthy control.

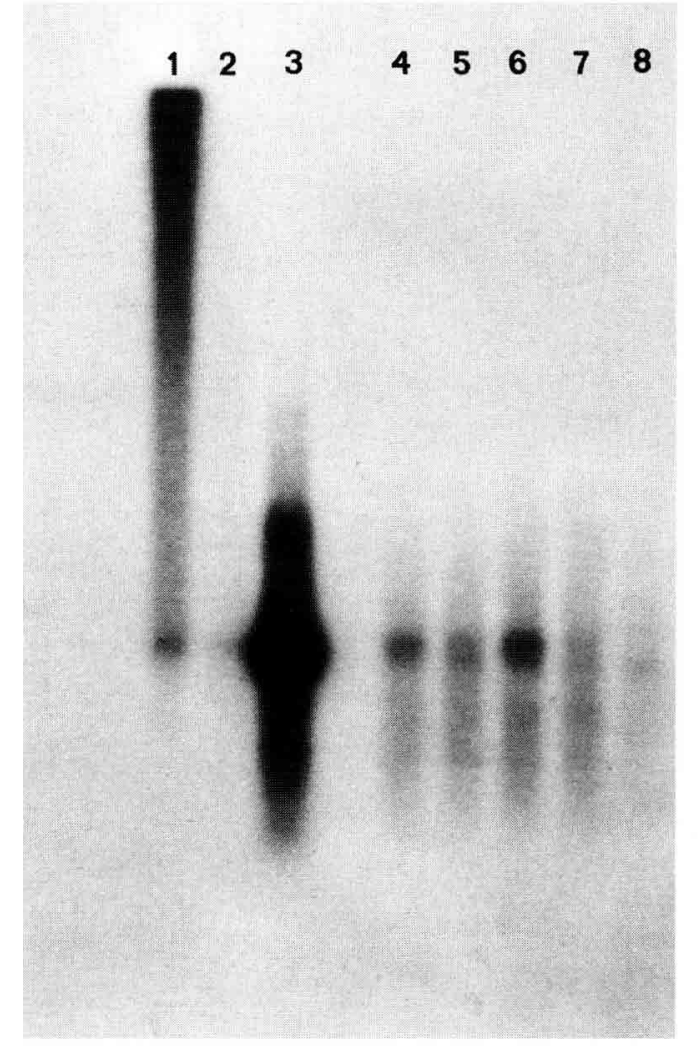

Fig 4. Southern blot of PCR products hybridized with a probe to the 530 bp PCR product from BLRV. Lanes 1-3: PLRV, BWYV and BLRV; lanes 4-7: luteovirus field samples D, Ena, $\checkmark$ and Dyt respectively; lane 8: healthy control.

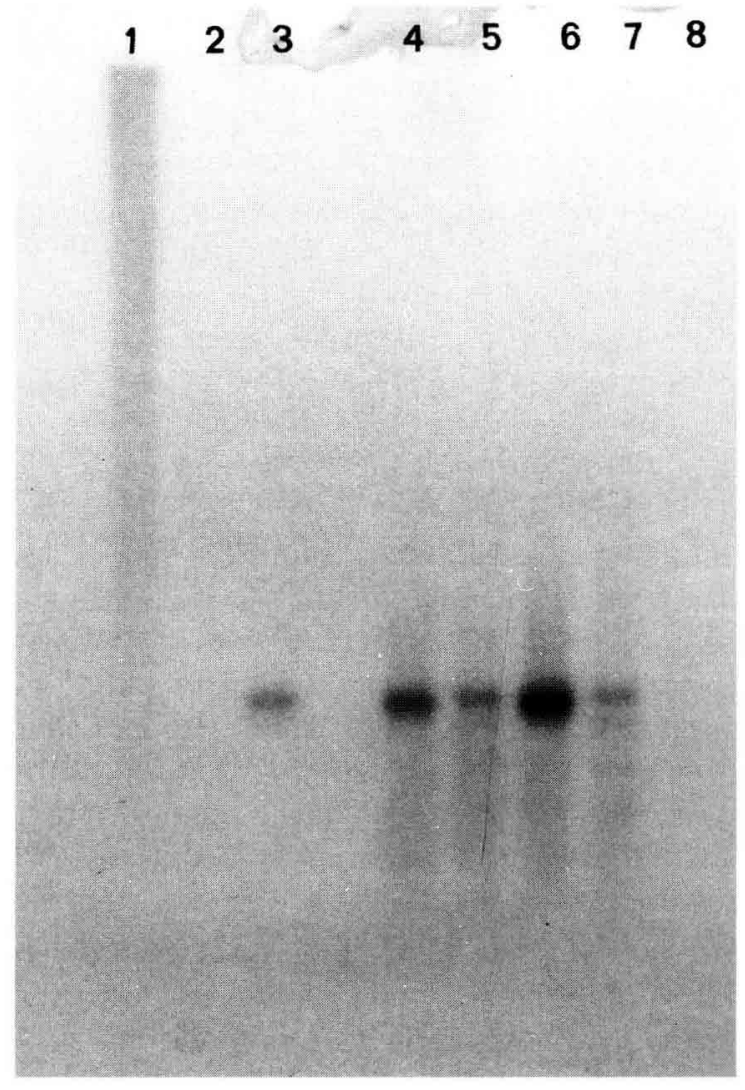

Fig 5. Southern blot of PCR products hybridized with a probe to the $530 \mathrm{bp}$ PCR product from the field isolate $\mathrm{V}$. Lanes 1-3: PLRV, BWYV and BLRV; lanes 4-7: luteovirus field samples $D$, Ena, $V$ and Dyt respectively; lane 8 : healthy control.

\section{SDS-PAGE}

Since the primer sets used in this study were designed to react with a wide array of luteoviruses, they possess hardly any discriminatory capacity. Moreover, they cannot discriminate between single and mixed infections of luteoviruses. To assess whether isolate $V$ differs from BLRV and BWYV, SDS-PAGE was performed to compare the mobility of the capsidassociated $(C A)$ proteins of these viruses. Figure 6 clearly shows that the CA proteins of isolate $V$ migrated differently from those of BWYV and BLRV, thus excluding the possibility of a mixed infection of BLRV and BWYV in field isolate $V$.

\section{DISCUSSION}

The 20 field samples of faba bean showing symptoms indicative of luteovirus infection reacted in ELISA with at least one of the antisera or MAbs used, suggesting that they were infected 


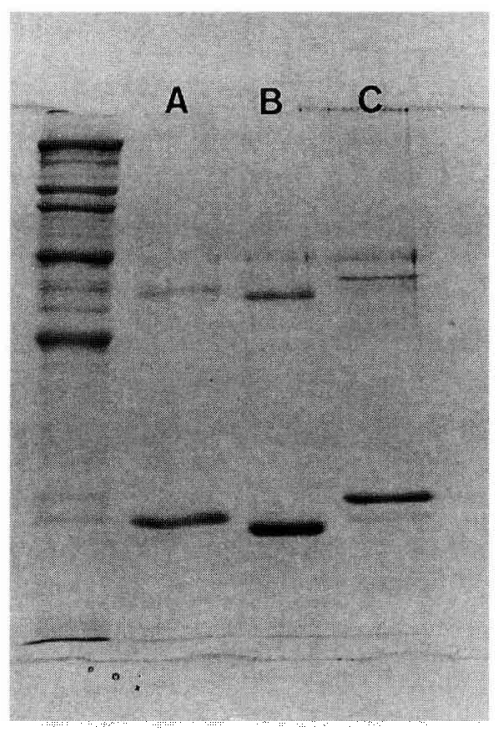

Fig 6. Migration patterns in SDS-PAGE of the luteovirus isolate $V(A), B W Y V(B)$ and BLRV (C) after staining with Coomassie Brilliant Blue. Left lane: protein markers.

with a luteovirus or a complex of luteoviruses. Based on their reactivities with the polyclonal antisera used, most of the samples reacted with the antiserum to BWYV, while some samples showed cross-reactions with two or even three antisera, and one sample scored negative in DAS-ELISA. Various serological relationships among the members of the luteovirus group have been reported (Waterhouse et al, 1988). It is therefore difficult to serologically identify most of the Moroccan isolates as one of the three luteoviruses known to infect legumes, particularly because the reaction patterns of our isolates obtained with polyclonal antisera were very diverse.

On the basis of the intensities of the reactions with the MAbs WAU-A12 and WAU-A24, as defined by Van den Heuvel et al (1990), two clusters of isolates were distinguished. The first cluster includes isolates which reacted strongly to WAU-A12 and moderately to WAU-A24 (B, I and $F$, for instance), and may be considered as BWYV-like isolates. The second cluster groups isolates which reacted moderately to both WAU$A 12$ and WAU-A24, and on this basis they appear different from both BWYV and BLRV. However, many of the isolates which reacted in a similar fashion to BWYV were also detected by antisera to BLRV and SCRLV. Since the three antisera did not cross-react, or gave only weak reactions with the heterologous positive controls in reciprocal assays (fig 1), it may well be that we have obtained BWYV isolates, but also other, possibly new luteoviruses or luteovirus strains.
However, affinity determination utilizing only two epitopes is likely to be too narrow a basis for virus identification. More serological studies are undoubtedly needed, and the diversity of reaction patterns points to considerable variation of the viruses under study.

In PCR, the set of primers Lu4/Lu1 previously used by Robertson et al (1991) to detect PLRV, BWYV, and different serotypes of barley yellow dwarf virus, did not amplify a fragment from BLRV. The pair of primers we designed (Lu4/VW66) amplified a fragment from PLRV, BWYV, and BLRV inoculated control plants, as well as luteovirus(es) in faba bean field samples. The sensitivity of PCR compared with other diagnostic techniques has been reported (Hadidi et al, 1993). It offers the additional advantage of providing amplified DNA fragments that would generate sequence information to be used to characterise unknown isolates.

To evaluate the suitability of the restriction enzyme analysis of the amplified PCR fragments in differentiating luteoviruses, as reported earlier (Robertson et al, 1991), preliminary tests were made with the BWYV-derived PCR product. The restriction pattern obtained, following digestion of the 535 bp PCR product by Sau 3Al, was different from that predicted from the known nucleotide sequence (Veidt et al, 1988). This is probably due to the variability of the virus and makes the differentiation of genetically non-characterized luteoviruses by this approach unreliable, especially when dealing with field isolates.

The hybridization tests involving the amplified 535 bp PCR products showed that the four field isolates $D$, Ena, Dyt and $V$, share nucleotide homology in their coat protein gene with BLRV, but not with BWYV. This conflicts with the serological data. The isolate $V$, for instance, appears to be serologically related to BWYV, but no cross-hybridization with BWYV could be detected. Moreover, this isolate differs in migration pattern of the coat protein in SDS-PAGE from BLRV and BWYV, which excludes the possibility of a mixed infection of both BLRV and BWYV. These observations further support the idea of the involvement of different luteovirus (or luteoviruses) adapted to the faba bean.

Luteoviruses form a continuum of serologically related members with overlapping host ranges (Waterhouse et al, 1988). As pointed out by Ashby and Johnstone (1985), we can envisage the possibility of evolution of different members of the group from an ancestral type as a result of the feeding preference of different aphid species, 
and BWYV is likely to be the ancestral type since its host range is wide and it is transmitted by a large number of aphid species. Host preferences of some aphid species may have favoured the selection and maintenance of luteovirus variants, thus evolving into a faba bean luteovirus sharing some properties with both BLRV and BWYV. Aphis craccivora, the prevailing aphid in faba bean fields in Morocco, may have played a crucial role in this process. However, characterization studies of some of the collected isolates, including the nucleotide sequences of their coat protein genes, will yield further insight into the identity of the luteoviruses infecting the faba bean in Morocco.

\section{ACKNOWLEDGMENTS}

The authors acknowledge JE Duffus, GR Johnstone, and $\mathrm{L}$ Katul for generously supplying the antisera, and $\mathrm{H}$ Huttinga and $\mathrm{F}$ Hans for critically reviewing the manuscript.

\section{REFERENCES}

d'Arcy CJ, Torrance L, Martin RR (1989) Discrimination among luteoviruses and their stains by monoclonal antibodies and identification of common epitopes. Phytopathology 79, 869-873

Ashby JW, Huttinga H (1979) Purification and some properties of pea leafroll virus. Neth J Plant Phatol 85, 113-123

Ashby JW, Johnstone GR (1985) Legume luteovirus taxonomy and current research. Aust Plant Pathol $14,2-7$

Avrameas S (1969) Coupling of enzymes to proteins with glutaraldehyde. Immunochemistry 6, 43-52

Casper R (1988). Luteoviruses. In: The Plant Viruses: Polyhedral Virions with Monopartite RNA Genomes volume 3 (R Koenig, ed), Plenum Press, New York, 235-258

Clark MF, Adams AN (1977) Characteristics of the microplate method of enzyme-linked immunosorbent assay for the detection of plant viruses. $J$ Gen Virol 34, 475-483

Duffus JE (1964) Host relationships of beet western yellows virus strains. Phytopathology 54, 736-738

Fortass M, Bos L (1991) Survey of faba bean (Vicia faba L) for viruses in Morocco. Neth J Plant Pathol 97, 369-380

Francki RIB, Fauquet CM, Knudson DL, Brown F (1991) Classification and nomenclature of viruses. Fifth report of the International Committee on Taxonomy of Viruses. Arch Virol Suppl 2, 309-311

Hadidi A, Montasser MS, Levy L et al (1993) Detection of potato leafroll and strawberry mild yellow-edge luteoviruses by reverse transcription-polymerase chain reaction. Plant Dis 77, 595-601

Johnstone GR, Duffus JE, Munro D, Ashby JW (1982) Purification of a Tasmanian isolate of subterranean clover red leaf virus, and its serological interactions with a New Zealand isolate and other luteoviruses. Aust J Agric Res 33, 697-703

Johnstone GR, Ashby JW, Gibbs AJ, Duffus JE, Thottappilly G, Fletcher JD (1984) The host range, classification and identification of eight persistent aphid-transmitted viruses causing diseases in legumes. Neth J Plant Pathol 90, 225-245

Laemmli UK, Favre M (1973) Maturation of the head of bacteriophage T4. DNA packaging events. J Mol Biol 80, 575-599

Martin RR, d'Arcy CJ (1990) Relationships among luteoviruses based on nucleic acid hybridization and serological studies. Intervirology 31, 23-30

Prill B, Maiss E, Katul L, Casper R (1990) Nucleoide sequence of the bean leafroll luteovirus coat protein gene. Nucl Acids Res 18, 5544

Quantz L, Völk J (1954) Die Blattrollkrankheit der Ackerbohne und Erbse, eine neue Viruskrankeiht bei Leguminosen. Nachrichtenbl Pflanzenschutzdienst Braunschweig 6, 177-182

Randles JW, Rathjen JP (1995) Genus Luteovirus. In: Virus Taxonomy, Sixth Report of the International Committee on Taxonomy of Viruses (FA Murphy, CM Fauquet, DHL Bishop et al, eds), SpringerVerlag, Vienna, 379-383

Robertson NL, French R, Gray SM (1991) Use of group-specific primers and the polymerase chain reaction for the detection and identification of luteoviruses. J Gen Virol 72, 1473-1477

Rochow WF, Duffus JE (1981) Luteoviruses and yellows diseases. In: Handbook of Plant Virus Infections; Comparative Diagnosis (E Kurstak, ed), Elsevier/North Holland Biomedical Press, Amsterdam, 147-170

Sambrook J, Fritsch EF, Maniatis T (1989) Molecular Cloning: A Laboratory Manual. Cold Spring Harbor Laboratory, New York

Van den Heuvel JFJM, De Blank CM, Goldbach RW, Peters D (1990) A characterization of epitopes on potato leafroll virus coat protein. Arch Virol 115, 185-197

Van der Wilk F, Huisman MJ, Cornelissen BJC, Huttinga $\mathrm{H}$, Goldbach RW (1989) Nucleotide sequence and organisation of potato leafroll virus genome. FEBS Lett 245, 51-56

Veidt I, Lot H, Leiser $M$ et al (1988) Nucleotide sequence of beet western yellows virus RNA. Nucl Acids Res 16, 9917-9932

Waterhouse PM, Gildow FE, Johnstone GR (1988) Luteovirus group. CMI/AAB Descriptions of Plant Viruses. No 339, $9 \mathrm{p}$

Wilson J, Close RC (1973) Subterranean clover red leaf virus and other legume viruses in Canterbury. NZ J Agric Res 16, 305-310 